\title{
A distinctive new species of the deep-water shrimp genus Glyphocrangon A. Milne-Edwards (Crustacea: Decapoda: Caridea: Glyphocrangonidae) from southern Australia
}

\author{
Tomoyuki Komai \\ Natural History Museum and Institute, Chiba \\ 955-2 Aoba-cho, Chuo-ku, Chiba 260-8682, Japan \\ E-mail: komai@chiba-muse.or.jp
}

\begin{abstract}
A distinctive new species of glyphocrangonid shrimp, Glyphocrangon elephas, is described on the basis of a single ovigerous female specimen from the Great Australian Bight, southern Australia, at a depth of $360 \mathrm{~m}$. The new species somewhat resembles G. hakuhoae Takeda and Hanamura from Indonesia and the Northwest Shelf and G. robusta Komai from the Philippines, but is characterized by a very strongly sinuous rostrum, very strong and elongate branchiostegal spine on the carapace, unusually thick and highly elevated median carinae on the abdomen and heavily crenulate ventrolateral margins of the telson. Glyphocrangon elephas is the first species of Glyphocrangonidae to be recorded from southern Australian waters. The discovery of the new species brings the number of Australian species of Glyphocrangon to 11 .
\end{abstract}

\section{INTRODUCTION}

Shrimps of the genus Glyphocrangon A. MilneEdwards, 1881 exclusively inhabit depths greater than $200 \mathrm{~m}$. They are characterized by the unusually hard body integument strongly sculptured by longitudinal carinae and/or tubercles, teeth or spines, and the peculiar locking mechanism of the posterior abdominal somites and telson. Recently Komai (2004) reviewed species of the genus in the Indo-West Pacific region, recognizing 54 species, including 28 new species. He suggested that intensive collections would eventually reveal existence of more unknown species from the Indo-West Pacific .

Examination of material in the collection of the Western Australian Museum, Perth, revealed a specimen of a distinctive undescribed species of Glyphocrangon. This new species, described herein as G. elephas, is compared with G. hakuhoae Takeda \& Hanamura, 1994, known from Indonesia and the Northwest Shelf and G. robusta Komai, 2004, from the Philippines. The new species represents the first species of Glyphocrangonidae to be recorded from southern Australia, as well as bringing the number of species of the genus known from Australia to 11.

Descriptive terminology generally follows Komai (2004). Size of the specimen is indicated by postorbital carapace length (CL). The holotype of the new species is deposited in the Western Australian Museum (WAM).

\section{SYSTEMATICS}

\section{Family GLYPHOCRANGONIDAE}

Genus Glyphocrangon A. Milne Edwards, 1881

Glyphocrangon elephas sp. nov. Figures 1-3

\section{Material Examined}

Holotype: Southern Australia: Great Australian Bight, $33^{\circ} 17^{\prime} \mathrm{S}, 128^{\circ} 32^{\prime} \mathrm{E}, 360 \mathrm{~m}, 19$ March 1978, trawl, coll. M. Walker, ovigerous female CL 13.6 $\mathrm{mm}$ (WAM-C 14783).

\section{Description}

Body (Figure 1) robust. Integument of carapace and abdomen naked, glabrous.

Rostrum (Figures 2A, B) moderately narrow in posterior part, strongly deepened at about midlength, 0.7 times of carapace length, directed downward in proximal part, but strongly upturned in distal half; dorsolateral ridges strongly sinuous in lateral view, with 2 pairs of short, rounded teeth; proximal part of dorsolateral ridge between 2 lateral teeth rather low, devoid of longitudinal groove, anterior part distal to anterior pair of lateral teeth highly elevated; middorsal carina low, confined to distal 0.2 of rostrum; dorsal surface lacking transverse septa or rugosity; ventral surface with shallow median groove becoming narrower 

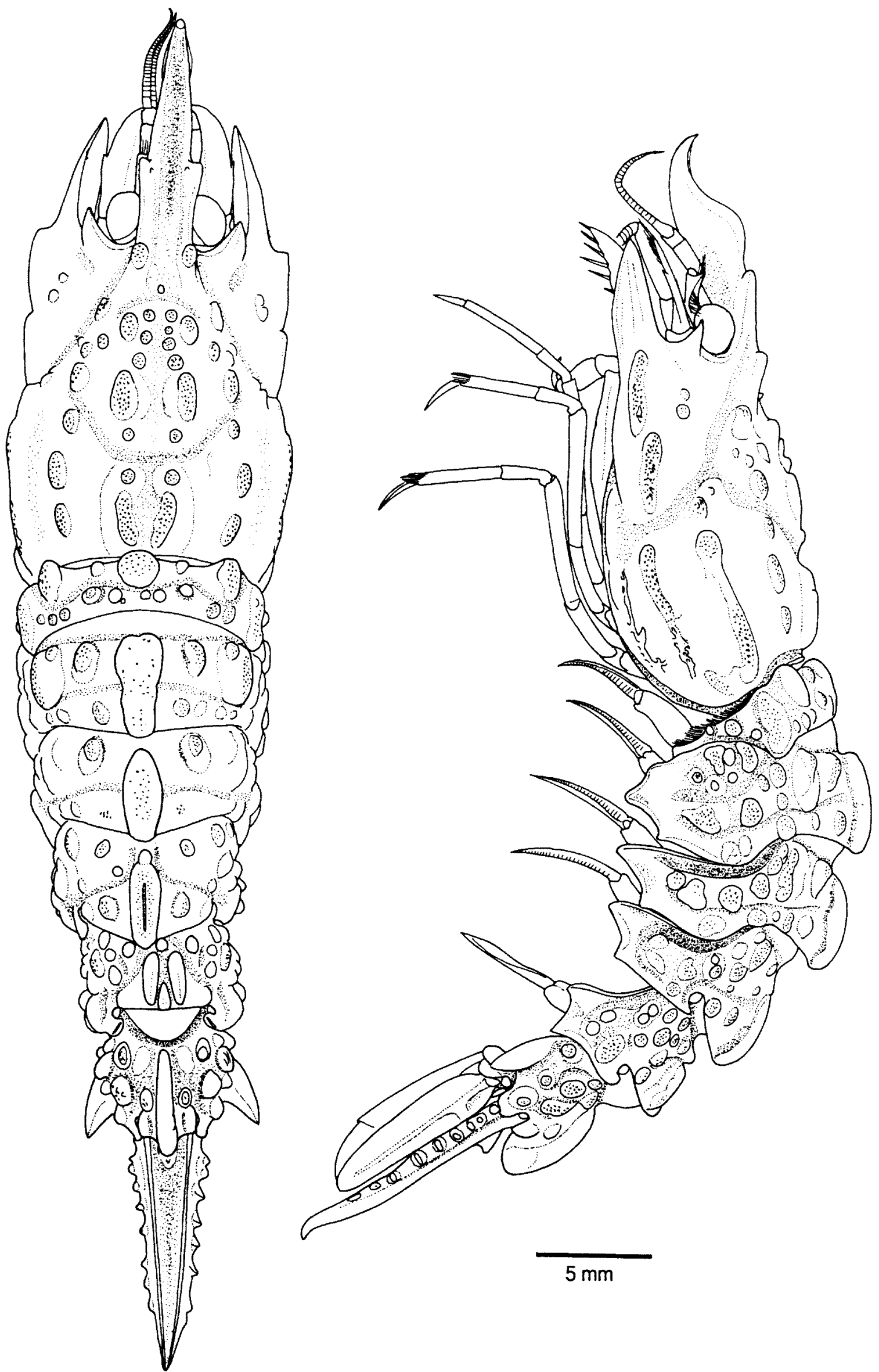

Figure 1 Glyphocrangon elephas sp. nov. Entire animal in dorsal and lateral views. Holotype ovigerous female (CL 13.6 $\mathrm{mm}$; WAM-C 14783). 
posteriorly, flanked by bluntly edged ventrolateral carinae; midventral carina absent.

Carapace (Figures 1, 2A, C) 1.1 times longer than greatest width at about midlength; carinae and tubercles eroded with minute pits. Anterior first (submedian) carina composed of 3 greatly unequal, low, blunt tubercles (first and second tubercles distinctly separated from each other, third tubercle longest); posterior first carina thick, faintly bi-lobed; posterior lobe converging to midline posteriorly, its posterior end not overhanging posterodorsal margin of carapace. Anterior second (intermediate) carina composed of 3 low, blunt tubercles; second, smallest tubercle aligned with other tubercles; posterior second carina composed of 3 low lobes (second lobe longest). Anterior third (antennal) carina very short, blunt, confined to antennal spine; posterior third carina low, broad, faintly 3-lobed (anteriormost lobe shortest), terminating obtusely at anterior end. Anterior fourth (lateral) carina divided in 2 discontinuous lobes, slightly unaligned; anterior lobe weakly compressed vertically, terminating anteriorly in blunt point; posterior lobe low, weakly compressed vertically, slightly divergent posteroventrad against dorsal plane of carapace, terminating anteriorly in blunt point; posterior fourth carina low, broad, parallel to posterior third carina. Anterior fifth (sublateral) carina low, but clearly delineated; posterior fifth carina very low, irregularly shaped, partially fused with posterior part of divided sixth (submarginal) carina. Sixth (submarginal) carina divided in two parts; anterior part low, roughly eroded; posterior part very low, irregularly shaped. Submarginal posteroventral ridge very low, distinct from sixth carina. Postorbital region unarmed, but with low, blunt submarginal ridge extending to antennal spine. Median part of gastric region with 2 rows of 3 or 4 tubercles on anterior part; posteromedian region smooth. Lateral part of gastric region with space between first and second carinae nearly flat, with 1 low tubercle; space between second carina and lateral groove narrow, also with 1 small, low tubercle. Posterior dorsolateral region slightly concave, smooth. Hepatic region with upper part only slightly convex, with row of 2 low tubercles, possibly representing trace of anterior third carina; lower part nearly flat, unarmed. Each part of branchial region unarmed. Subbranchial region with space between anterior fifth and sixth carinae moderately broad, shallowly depressed below, smooth, in contact with lower part of branchial region. Antennal spines short, nearly straight in dorsal view, weakly ascending in lateral view (angle about $15^{\circ}$ against horizontal plane of carapace). Branchiostegal spines very strong, visible in dorsal view, directed forward in both lateral and dorsal views, extending to distal margin of antennal scale; lateral face with 2 inconspicuous ridges, not in contact with anterior fourth carina. Marginal posterolateral corner not delineated. Lateral and cervical grooves shallow. Lateromarginal groove shallow.

First abdominal somite (Figure 1) with dorsal elevation low, but clearly defined by shallow transverse groove, with 1 blunt tubercle on either side of median carina; median carina low, very broad, not reaching posterodorsal margin of somite, terminating anterodorsally in broadly rounded projection. Dorsolateral carina low, thick, with rounded anterior margin. Posterior section of tergum with 5 or 6 low tubercles on either side of midline. Lateral carina low, broad, entire. Pleuron with 1 blunt submarginal tubercle anterolaterally; posterior depression not abruptly delimited; anteroventral corner weakly produced, blunt.

Second to fourth abdominal somites (Figure 1) with only few intercarinal tubercles; surfaces of carinae and tubercles minutely punctate; median carinae unusually thick, posterior ends each weakly to somewhat produced posteriorly; cross sections of median carinae T-shaped; posterior transverse grooves very shallow; dorsolateral carinae showing as low, rounded tubercles; pleura each with some large, low tubercles or protuberances; ventral lobes of pleural elevations lacking prominent tubercle or spine; pleural teeth greatly unequal, blunt, only slightly curved laterally.

Fifth abdominal somite (Figure 1) humpy with rounded tubercles; anterior median carina showing as blunt tubercle; posterior median carina short, thick, its posterior end rounded. Tergum with shallow dorsal groove; anterior submedian carina showing as blunt tubercle; posterior submedian carinae high, thick, reaching nearly to posterodorsal margin of somite, slightly diverging posteriorly in dorsal view; pleuron with 2 short ventral teeth.

Sixth abdominal somite (Figure 1) with high, somewhat compressed median carina, entire, terminating posteriorly in large, blunt projection; dorsal margin smooth, convex in lateral view. Tergum with 1 large, rounded tubercle on either side of median carina; lateral carina composed of 2 large tubercles; posterolateral carina distinct, slightly produced beyond posterolateral margin of somite. Pleuron with 5 large tubercles; lateroventral carina extending onto posterolateral tooth; posterolateral tooth strong, rather subacute, noticeably flared laterally.

Telson (Figures 1, 2E) 0.8 times as long as carapace; anterior projection moderately high, somewhat compressed laterally, directed posteriorly; dorsolateral carina smooth; ventrolateral carina strongly crenulate almost over entire length with short vertical tubercles or rounded tubercles.

Eye (Figures 1, 2A) relatively small for genus, maximal diameter 0.15 of carapace length, without 


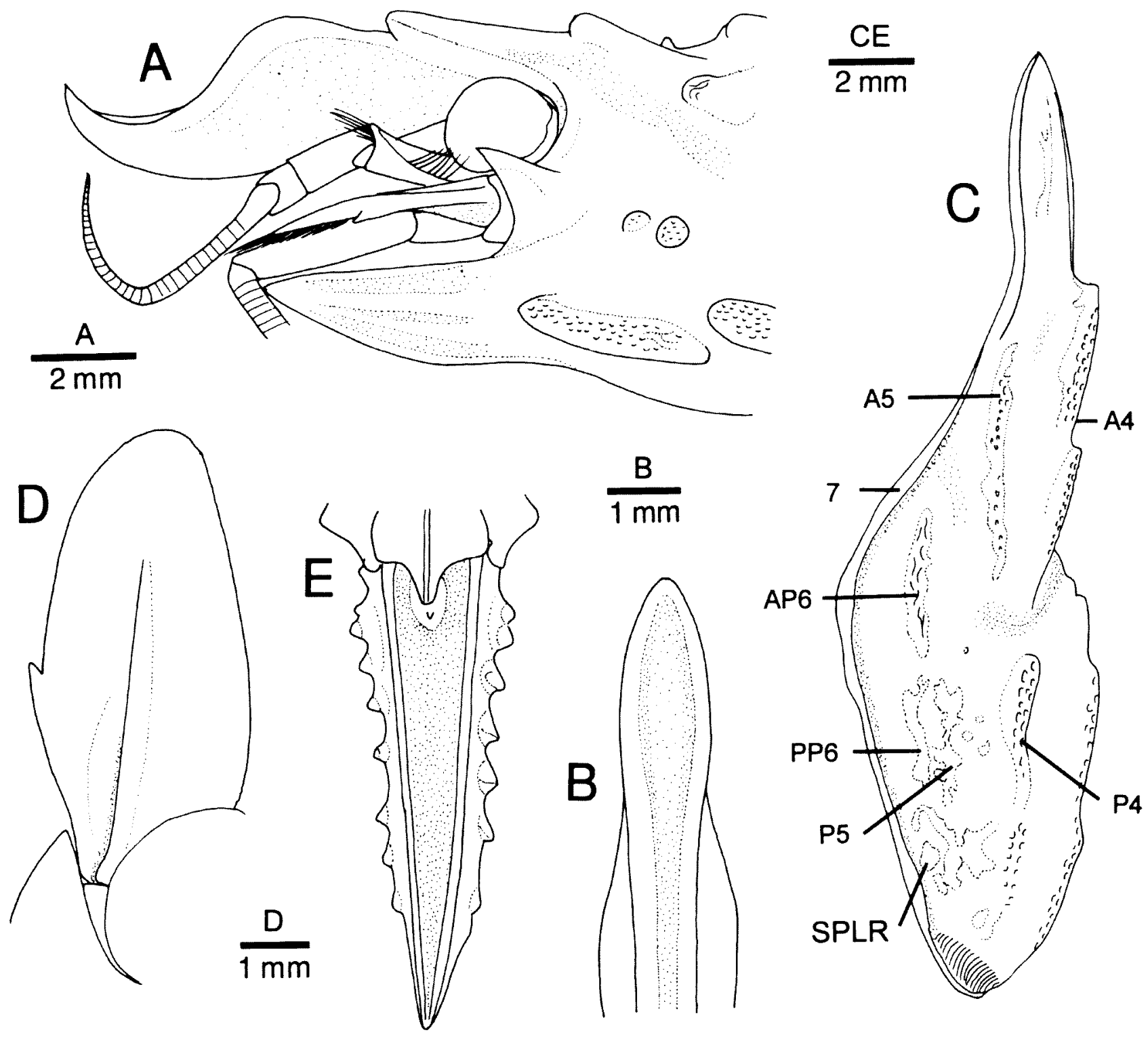

Figure 2 Glyphocrangon elephas sp. nov. A, anterior part of carapace and cephalic appendages, lateral view (antennal flagellum omitted); B, rostrum, ventral view; $C$, ventral part of carapace, ventrolateral view; $D$, left antennal scale, dorsal view; E, telson, dorsal view. Holotype ovigerous female (CL 13.6 mm; WAM-C 14783). Abbreviations: A4, anterior fourth carina; A5, anterior fifth carina; AP6, anterior part of sixth carina; P4, posterior fourth carina; P5, posterior fifth carina; PP6, posterior part of sixth carina; SPLR, submarginal posterolateral ridge; 7 , seventh carina.

dark pigmentation in preservative; ocular peduncle with small anteromesial process.

Antennular peduncle (Figure 1, 2A) reaching distal margin of scaphocerite; penultimate segment twice as long as wide. Outer flagellum with moderately long aesthetasc-bearing portion.

Antennal scaphocerite (Figures 1, 2A, D) elongate oval, 0.33 times as long as carapace, 2.20 times longer than wide; dorsal surface naked; lateral margin weakly convex, with distinct lateral tooth arising at proximal 0.44 of scaphocerite length. Carpocerite not reaching distal margin of scaphocerite.

Mouthparts not dissected, but typical of genus. Third maxilliped slightly overreaching distal margin of scaphocerite; marginal spines on distal 2 segments slender.

First pereopod (Figure 3A) with palm devoid of pubescence or short setae on lateral face; ischium with moderately broad, distally acute ventral lamina. Second pereopods (Figure 3B) slightly unequal with right chela smaller; neither reaching distal margin of scaphocerite; left carpus composed of 22 articles. Posterior 3 pairs of pereopods moderately stout. Third pereopod (Figure 3B) overreaching distal margin of scaphocerite by length of dactylus; propodus without distal tuft of setae. Fourth pereopod (Figure 3D) reaching distal margin of scaphocerite by tip of dactylus; dactylus (Figure 3E ) 0.78 times as long as propodus, 


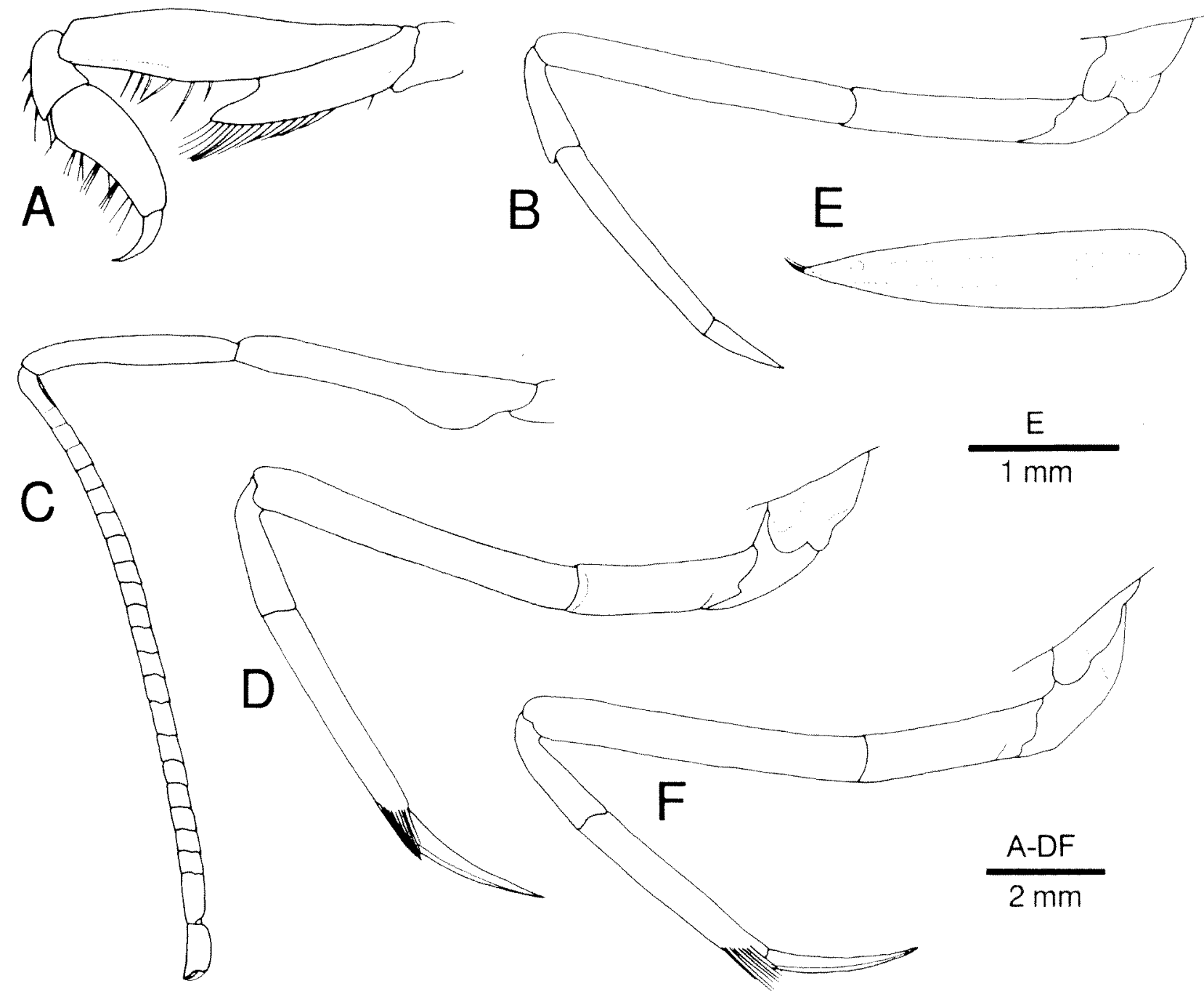

Figure 3 Glyphocrangon elephas sp. nov. Left pereopods. A, first pereopod, lateral view; B, second pereopod, lateral view; $C$, third pereopod, lateral view; D, fourth pereopod, lateral view; E, dactylus of fourth pereopod, dorsal view; F fifth pereopod, lateral view. Holotype ovigerous female (CL $13.6 \mathrm{~mm}$; WAM-C 14783).

subspatulate, terminating in simple, acuminate unguis partially obscured by tufts of setae arising from just lateral to base of unguis; dorsal surface shallowly broadly sulcate medially, without distolateral groove; ventral surface not carinate in midline. Fifth pereopod (Figure 3F) overreaching midlength of scaphocerite by tip of dactylus; dactylus 0.73 times as long as propodus, generally similar to that of fourth pereopod in structure.

Egg size 1.53-1.76 x 1.24-1.47 mm; number not recorded.

\section{Distribution}

Known only from the Great Australian Bight, southern Australia, at a depth of $360 \mathrm{~m}$.

\section{Remarks}

Glyphocrangon elephas sp. nov. somewhat resembles $G$. hakulone from Indonesia and the Australian Northwest Shelf and G. robusta from the
Philippines, and together differ from all other congeners by the combination of the strongly sinuously curved dorsolateral margins of the rostrum in female and the two unaligned lobes composing the anterior fourth (lateral) carina on the carapace. However, the new species is quite distinctive in having unusually thick and highly elevated median carinae on the second to fourth abdominal somites and the very strongly sinuous rostrum. Other characteristics of the new species include: the branchiostegal spine is very strong, reaching the distal margin of the scaphocerite; and the ventrolateral carina of the telson is strongly crenulate with short vertical ridges or rounded tubercles.

Komai (2004) recorded the following 10 species of Glyphocrangon from Australian waters (Table 1): $G$. confusa Komai, 2004 (previously known from Australia as G. ineestigatoris Wood-Mason, in Wood-Mason and Alcock, 1891; see Jones \& 
Table 1 Summary of the geographical distribution of species of Glyphocrangon known from Australia.

\begin{tabular}{lll}
\hline $\begin{array}{l}\text { Western } \\
\text { Australia }\end{array}$ & $\begin{array}{l}\text { Eastern } \\
\text { Australia }\end{array}$ & $\begin{array}{l}\text { Southern } \\
\text { Australia }\end{array}$ \\
\hline G. confusa & G. holthuisi & G. elephas sp. nov. \\
G. faxoni & G. kapala & \\
G. hakuhoae & G. lowryi & \\
G. lineata & G. novaecastellum & \\
G. pugnax & G. tasmanica & \\
\hline
\end{tabular}

Morgan, 1994, 2002; Davie, 2002), G. faxoni De Man, 1918, G. hakuhoae, G. holthuisi Kensley, Tranter \& Griffin, 1987, G. kapala Komai, 2004 (previously referred to G. assimilis De Man, 1918 by Kensley et al. (1987)), G. lineata Komai, 2004, G. lowryi Kensley, Tranter \& Griffin, 1987, G. novaecastellum Kensley, Tranter \& Griffin, 1987, G. pugnax De Man, 1918 and G. tasmanica Komai, 2004. It is remarkable that the species composition is quite different between western and eastern Australia, although the numbers of the species occurring in those regions are similar (five species are known from Western and Eastern Australia, respectively). There are no common species between the two regions. The marine fauna of Western Australia contains many Indonesian elements, probably owing to the south flowing Leeuwin Current (e.g., Garrey et al., 1981). In fact, all species of Glyphocrangon recorded from the Northwest Shelf are commonly found in Indonesian waters. In contrast, all known species from eastern Australia appears to be endemic. From southern Australia, so far, only Glyphocrangon elephas is known.

\section{Etymology}

From the Latin elephas (elephant), in reference to the elephant nose-like rostrum with strongly sinuous dorsolateral margins. It is used as a noun in apposition.

\section{ACKNOWLEDGEMENTS}

I am grateful to Diana Jones of the Western Australian Museum for providing material. I also thank Drs. Peter J. F. Davie and Shane T. Ahyong for reviewing the manuscript and offering helpful comments for improvements.

\section{REFERENCES}

Davie, P. J. F. (2002). Crustacea: Malacostraca: Phyllocarida, Hoplocarida, Eucarida (Part 1). In Wells, A. and Houston, W. W. K. (eds), Zoological Catalogue of Australia 19.3A. CSIRO Publishing, Melbourne.

Garrey, J., Maxwell, H., and Cresswell, G. R. (1981). Dispersal of tropical marine fauna to the Great Australian Bight by the Leeuwin Current. Journal of Marine and Freshwater Research 32: 493-500.

Jones, D. S and Morgan, G. J. (1994). A field guide to crustaceans of Australian waters. Reed, New South Wales.

Jones, D. S. and Morgan, G. J. (2002). A field guide to crustaceans of Australian waters. Reed, New South Wales.

Kensley, B., Tranter, H. A., and Griffin, D. J. G. (1987). Deep-water decapod Crustacea from eastern Australia (Penaeidea and Caridea). Records of the Australian Museum 39: 263-331.

Komai, T. (2004). A review of the Indo-West Pacific species of the genus Glyphocrangon A. Milne Edwards, 1881 (except for G. caeca Wood-Mason, 1891 species group) (Decapoda: Caridea: Glyphocrangonidae). In Marshall, B. and Richer de Forges, B. (eds.), Tropical Deep Sea Benthos Vol. 23. Memoires du Museum national d'Histoire naturelle, Paris 191: 375-610.

Man, J. G. de. (1918). Diagnoses of new species of macruran decapod Crustacea from the SibogaExpedition. Tijdschrift der Nederlandsche Dierkundige Vereeniging (2) 16: 293-306.

Milne-Edwards, A. (1881). Description de quelques Crustacés macroures provenant des grandes profondeurs de la mer des Antilles. Annales des Sciences Naturelles, Zoologie (6) 11: 1-16.

Takeda, M. and Hanamura, Y. (1994). Deep-sea shrimps and lobsters from the Flores Sea collected by the R.V. Hakuho-maru during KH-85-1 cruise. Bulletin of the National Science Museum, Series A (Zoology) 20: 1-37.

Wood-Mason, J. and Alcock, A. (1891). Natural history notes from H.M. Indian marine survey steamer "Investigator," Commander R. F. Hoskyn, R.N., commanding. Notes on the results of the last season's deep-sea dredging. Annals and Magazine of Natural History (6) 7: 186-202, 353-362.

Manuscript received 25 May 2004; accepted 22 September 2004 